\title{
EFFECT OF TYLOSIN ON RUMEN FERMENTATION IN VITRO
}

\author{
S. B. CHON ${ }^{1}$, Oxana G. SAVKA ${ }^{2}$, P. BREEZINA ${ }^{3}$ and M. MAROUNEK ${ }^{4 *}$
}

1. Institute of Experimental Biology, Pyongyang, Korean D. P. R.

2. Ukrainian Research Institute of Physiology and Biochemistry of Farm Animals, Lvov, USSR

3. Institute of Chemical Technology, Dept. of Dairy Science, Prague 6

4. Institute of Animal Physiology and Genetics, Czechoslovak Academy of Sciences, 10400 Präha 10 - Uhřiněves

Received June 1, 1989

\section{Abstract}

Ch on S. B., Ox a n a G. S a vka, P. B y z in a, M. M a roun e k: Effect of Tylosin on Rumen Fermentation in vitro. Acta vet. Brno 58, 1989:313-321.

The effects of tylosin on production of end-products of carbohydrate metabolism, utilization of lactic acid and degradation of protein were investigated in in vitro experiments with rumen inocula. Tylosin non-specifically inhibited the rumen fermentation with inocula from non-adapted cows, but most of its effects disappeared when inocula wera taken from adapted wethers. Production of lactic acid was severely depressed by tylosin, no matter whether inocula originated from non-adapted or adapted animals. Some other tylosin-induced metabolic effects differed from those of ionophore compounds, in spite of the fact, that both tylosin and ionophores are potent gram-positive antibiotics.

\section{Cattle, wethers, rumen fluid, incubation}

Tylosin is a macrolide antibiotic produced by Streptomyces fradiae that is a potent inhibitor of the proteosynthesis in many gram-positive bacteria. Several researchers have demonstrated that continuous low-level feeding of tylosin reduced the incidence and severity of liver abscesses, increased average daily gains and improved feed conversion of feedlot cattle (B r o w n et al. 1973; $\mathrm{H}$ e i $\mathrm{n}$ e $\mathrm{m}$ a $\mathrm{n}$ $\mathrm{n}$ et al. 1978; P o $\mathrm{t} \mathrm{t}$ e $\mathrm{r}$ et al. 1985). The liver-protecting effect tylosin is based on its inhibitory influence on Fusobacterium necrophorus (previously recognized as Sphaerophorus necrophorus), a bacterium that was isolated from $95 \%$ of the abscess specimens in experiments of $\mathrm{B} \mathrm{r} \mathrm{o} \mathrm{w.} \mathrm{n}$ et al. (1973). The combination of monensin and tylosin has been cleared for commercial use as the feed additive in the cattle industry in the USA nowadays and similar ionophore/tylosin combinations are being tested (G i 11 and $\mathrm{O}$ w e n s 1984; S t r a s i a and J o r d a n 1985).

Although the addition of tylosin to ruminant diets seems to be promising, little information is currently available on its effect on the rumen fermentation. P u r s e r et al. (1965) found that volatile fatty acid (VFA) distribution was modified towards more butyrate and less propionate in tylosin-fed wethers. Rumen protozoal numbers were increased following antibiotic supplementation while no differences were observed in the total viable bacteria counts. Similar effects of tylosin on the molar composition of VFA were found by $\mathrm{O}^{\prime} \mathrm{C}$ o $\mathrm{n} \mathrm{n}$ o $\mathrm{r}$ et al. (1970) in vitro. $\mathrm{N}$ a $\mathrm{g}$ a $\mathrm{r}$ a j a and $\mathrm{T}$ a y 1 o r (1987) mentioned briefly that tylosin increased acetate and decreased propionate in their batch culture fermentations. The susceptibility and resistance of pure cultures of rumen bacteria to tylosin have been reported in several studies (E $1 \mathrm{Ak}$ k a d and $\mathrm{H} \mathrm{o.b} \mathrm{s} \mathrm{o} \mathrm{n}$ 1966; W a $n g$ et al. 1969; $\mathrm{N}$ a g a r a a and T a y 1 o r 1987; $\mathrm{M}$ a r o u n e k et al. 1988). Tylosin inhibited the growth of rumen gram-positive bacteria and those bacteria which often stain gram-negatively, but possess cell walls with gram-positive ultrastructure, such as Butyrivibrio fibrisolvens and the ruminococci.

The purpose of this work was to define better effects of tylosin on rumen fermentation in vitro. We aslo watend to test the hypothesis of $\mathrm{R} \mathrm{u} \mathrm{s} \mathrm{e} 11$ and $\mathrm{S} \mathrm{t} \mathrm{r} \mathrm{o} \mathrm{b} \mathrm{e} 1$ (1988) who suggested that any gram-positive antibiotic can produce fermentation shifts, similar to those of monensin. Their experiments showed that bacitracin a polypeptide gram-positive antibiotic, produced fermenta-

* Corresponding author 
tion effects that resembled very much alternations in rumen stoichiometry observed with ionophores. Our in vitro experiments were performed using rumen fluid from both non-adapted and adapted animals.

\section{Material and Methods}

\section{a) General remarks}

Samples of rumen contents were taken from rumen fistulated animals (two cows or two wethers), two hours after the morning feed. The animals were fed twice a day. The cows weighing about $550 \mathrm{~kg}$ were fed with $2 \mathrm{~kg}$ of concentrate, $6 \mathrm{~kg}$ of meadow hay and $10 \mathrm{~kg}$ of maize silage per day. The wethers, weighing $50 \mathrm{~kg}$, were fed with $0.8 \mathrm{~kg}$ of meadow hay and $0.4 \mathrm{~kg}$ of a commercial concentrate mixture, supplemented with $200 \mathrm{mg}$ of tylosin (Elanco) per day for two months. Rumen fluid was prepared from whole rumen contents by straining through two layers of chese cloth. Its average pH was 6.70 and 6.67 for cows and wethers, resp. The in vitro incubations were carried out as deseribed previously ( $M$ a r o u $\mathrm{n}$ e $\mathrm{k}$ et al. 1983). Tylosin was added at 0-2-5-10 and $20 \mathrm{mg} / 1$, final concentration. Each experimental or control arrangement was incubated in four replicates.

Six experiments were performed with the rumen fluid from non-adapted cows (No. 1-6) and eight experiments with the rumen fluid adapted wethers (No. I-VIII). Two experiments (No. 5 and No. $V$ were performed at low pH values, all others in the physiological pH interval (pH 6-7).

\section{b) Incubations}

E x p e r i m e n t 1. Glucose ( $1.5 \mathrm{~g}$ ) was dissolved in $100 \mathrm{ml}$ of Mc Dougall buffer containing sources of nitrogen, vitamins and microelements, then $50 \mathrm{ml}$ of rumen fluid were added. The cultures were incubated anserobically at 39 PC for 6 hours.

E x p e r i m e n t 2. Maize starch $(3 \mathrm{~g})$ was suspended in $100 \mathrm{ml}$ of buffer and the $50 \mathrm{ml}$ of rumen fluid were added. The cultures were incubated 8 hours.

Experiment 3. Whatman filter paper No. 1 was ground and added $(3 \mathrm{~g})$ to $100 \mathrm{ml}$ of buffer and $50 \mathrm{ml}$ of rumen fluid. The incubation time was 20 hours.

E x p e r i m e n t 4. Citrus pectin (Genu Pektin from the Pectin Factory Ltd., Copenhagen, commercial quality) was dissolved in buffer $(2 \mathrm{~g} / 100 \mathrm{ml})$ and $50 \mathrm{ml}$ of rumen fluid were added. The cultures were incubated 7 hours.

EX p e r i m e n t 5 . In this experiment $1.5 \mathrm{~g}$ of sucrose and $3 \mathrm{~g}$ of soluble starch were added to $100 \mathrm{ml}$ of buffer and $50 \mathrm{ml}$ of rumen fluid. The $\mathrm{pH}$ was kept between 5 and 6 , to achieve a high production of lactic acid. The incubation time was 7 hours.

Ex p e r i m e n t 6 . Sodium lactate was dissolved in buffer $(50 \mathrm{mmol} / \mathrm{l})$, then rumen fluid was added $(100 \mathrm{ml}+50 \mathrm{ml})$. The incubation time was 7 hours.

E X p e r i m e $\mathrm{n}$ s $1-6$ were perfomed using the same substrate and incubation conditions, except that adapted wethers instead of non-adapted cows served as donors of inocula and the lowest concentration of tylosin $(2 \mathrm{mg} / 1)$ was omitted.

E X p e r i m e n t VII. In this experiment we estimated the effect of tylosin on production of VFA and methane from the mixture of sodium carboxymethylcellulose (Koch Light Laboratories, Ltd, UK), maize starch and glucose in ratio 9:9:2. The mixed substrate (27 g) was added to $600 \mathrm{ml}$ of bufier and $300 \mathrm{ml}$ of rumen fluid. Tylosin was added at $10 \mathrm{mg} / \mathrm{h}$, final concentration into one incubation vessel, whereas control received no tylosin. Fermentation gas was collected in calibrated glass cylinders, equipped with three-ways valves. The incubation was completed after 11 hours.

E X p e r i m e n t V I I I. Casein from Fluka (1.5 g) and glucose (1.5 g) were added to $100 \mathrm{ml}$ of buffer and $50 \mathrm{ml}$ of rumen fluid. The cultures were incubated 6 hours.

\section{c) Analyses}

Total VFA were estimated by titration after steam distillation. Their molar composition was determined by gas liquid chromatography using a column of the Inerton AW $(0.25-0.32 \mathrm{~mm})$ with $10 \%$ Reoplex 100 (Lachema, Brno, Czechostovakia); lengt $1.8 \mathrm{~m}$. A Chrom 4 gas chromatograph (Laboratory Instruments, Prague) equipped with a FI detector was used. The separation was carried out at $125^{\circ} \mathrm{C}$ and an inlet pressure of $150 \mathrm{kPa}$. The same column and de- 
tector were used for the determination methane at room temperature and at an inlet pressure of $40 \mathrm{kPa}$. Lactate was oxidized to acetaldehyde and measured in microdiffusion chambers ( $\mathrm{C}$ o $\mathrm{n}$ w a y 1957). Protein was measured according to $L$ o w r y (1951).

\section{Results}

Effects of tylosin on production of VFA and lactate from. carbohydrates are shown in Figs. 1-4. Tylosin had little effect on production of butyrate in experiments with inocula taken from non-adapted cows (Fig. 1). The total VFA, acetate and propionate were decreased in tylosin-treated cultures. The molar ratio acetate to propionate was lowered by tylosin in cultures with starch and pectin, but increased in cultures with glucose and cellulose. Contrary to this, the total VFA and their molar composition were unchanged in experiments with inocula from adapted wethers. The addition of tylosin resulted in considerably lower production of lactic acid, both with non-adapted and adapted cultures (Figs. 1 and 3). The utilization of lactic acid was lowered in tylosin-treated cultures with inocula from cows and to a smaller extent also in cultures with inocula from adapted wethers (Figs. 1 and 3). Tylosin also diminished production of methane and degradation of protein (Figs. 4 and 5). These experiments were performed using adapted inocula only.

\section{Discussion}

In our experiments tylosin inhibited rumen fermentation in vitro with inocula taken from non-adapted animals, but most of its effects disappeared when inocula originated from adapted animals. This adaptation effect was probably caused by selection of bacterial strains resistant to tylosin, although other mechanism can not be excluded, e. g. the inactivation of the antibiotic, the alteration of its target site or the block in transport. The most pronounced effect of tylosin was its inhibitory influence on the production of rumen lactate, that persisted in animals adapted to high doses of the antibiotic. Tylosin was much more effective in this respect than monensin in our previous experiments ( $M$ a r o u n e k et al. 1988). This lactate-depressing property can be related to the inhibitory effect of tylosin on gram-positive bacteria, that are principal lactate producers in the rumen. Surprisingly, the microscopic appearance of the rumen fluid was not much changed after adaption and gram-positive bacteria were still present. The decrease in methane production was proportional to the decrease in VFA (Fig. 4); this finding supports the assumption that tylosin has little direct effect on methanogens.

Russe l and Strobel (1988) stated that any gram-positive antibiotic may produce effects similar to those of monensin. In our experiments tylosin, a potent gram-positive antibiotic, exerted only partially effects on the molar composition of VFA, that are typical for monensin and other ionophores. Neither penicillin, another gram-positive antibiotic, resembled monensin in experiments of O' C o n n or et al. (1970) and B e e de and Fa rli in (1977).

In conclusion, the addition of tylosin to monensin-supplemented or monensin-free diets may be benefitial for ruminants, thanks to its liver-protecting, lactate-depressing and protein-sparing effects. 
Exp No

1.
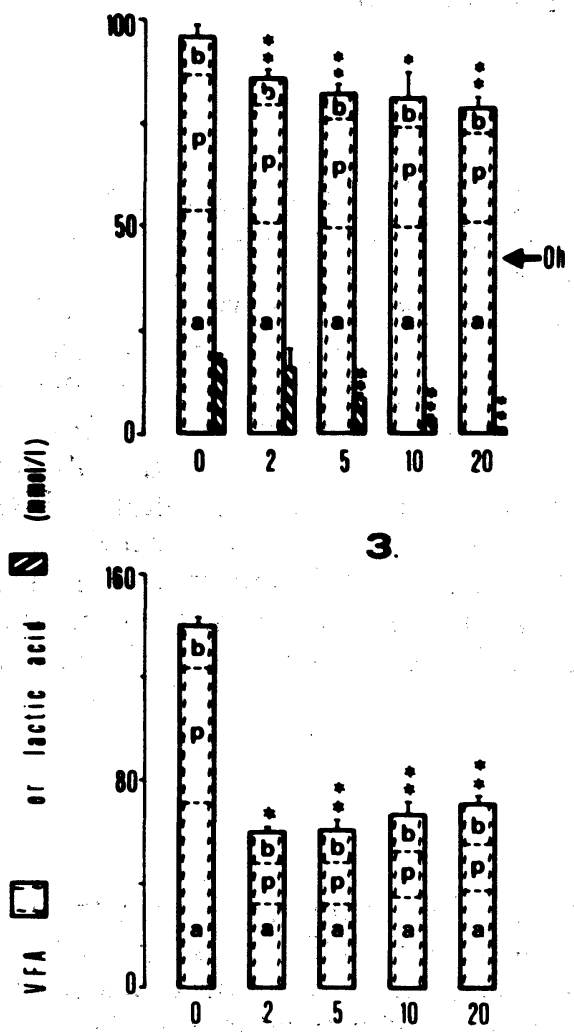

2.

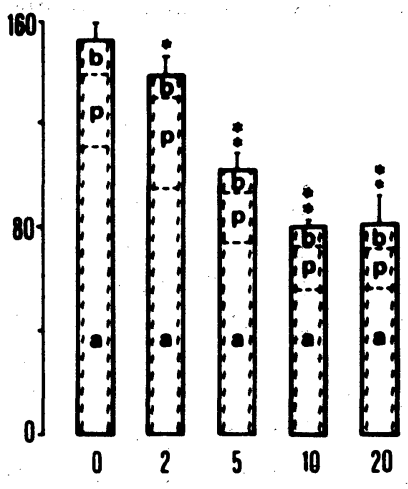

4.

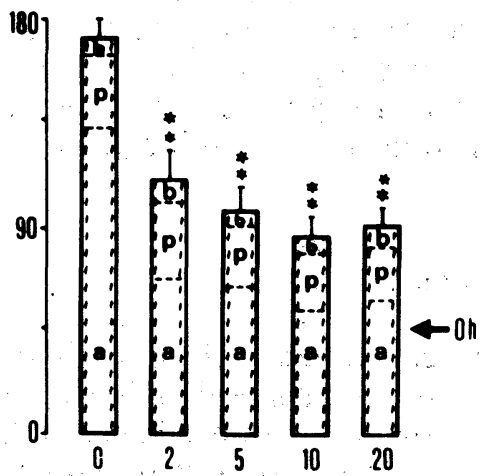

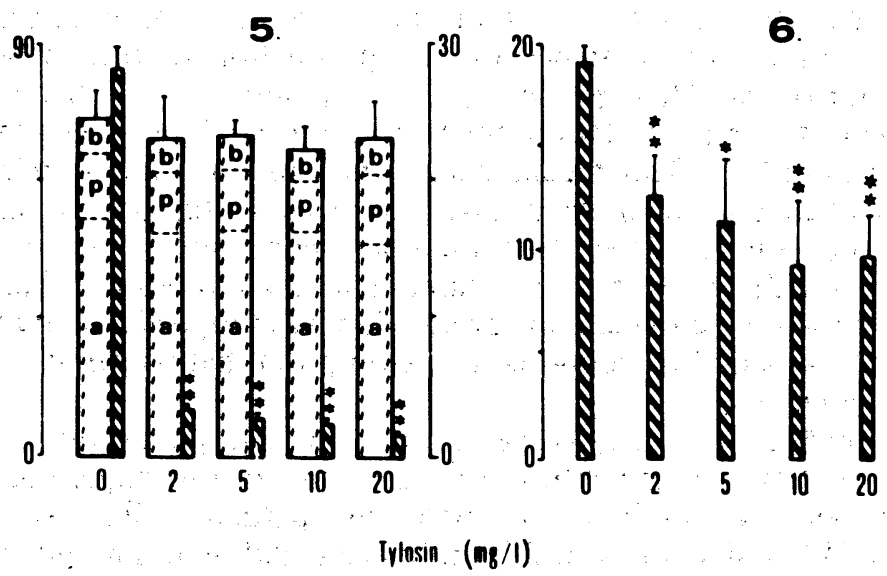

Fig. 1 Effect of tylosin on ir vitro rumen fermentation with inocula from non-adapted cows. Substrates were glucose (1), starch (2), cellulose (3), pectin (4), sucrose and starch at low pH (5) and lactate (6).

$\mathrm{a}$ - acetate, $\mathrm{p}$ - propionate, $\mathrm{b}$ - butyrate

$*-\mathrm{P}<0.05, *$ * $-\mathrm{P}<0.005$ 
Exp. No.

I.

120

80

0

$\overline{\underline{\underline{\underline{E}}}}$

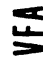

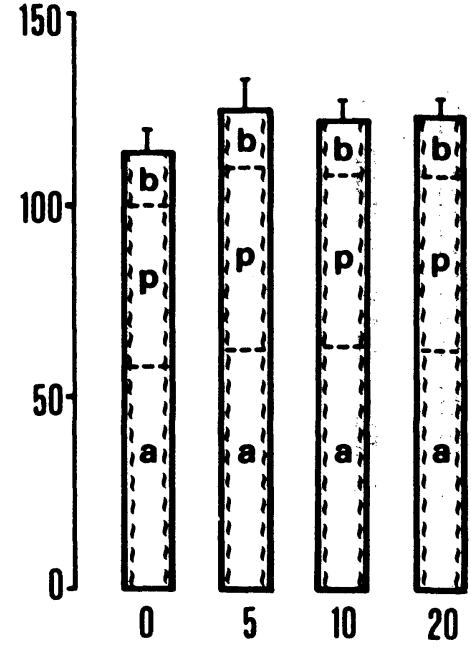

II.

120

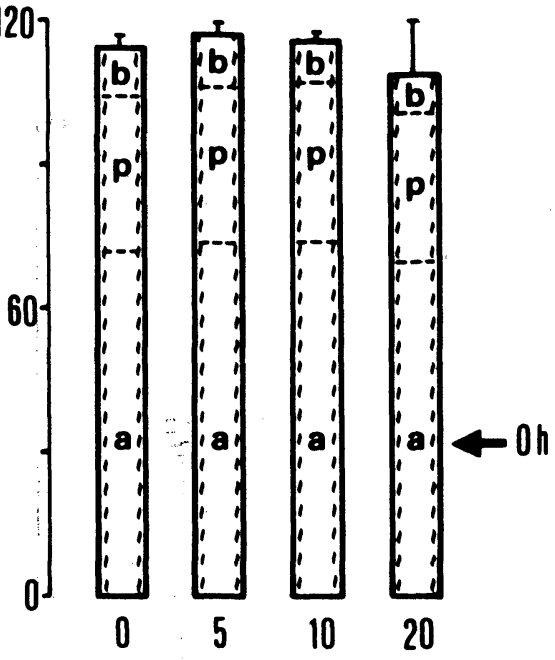

产.

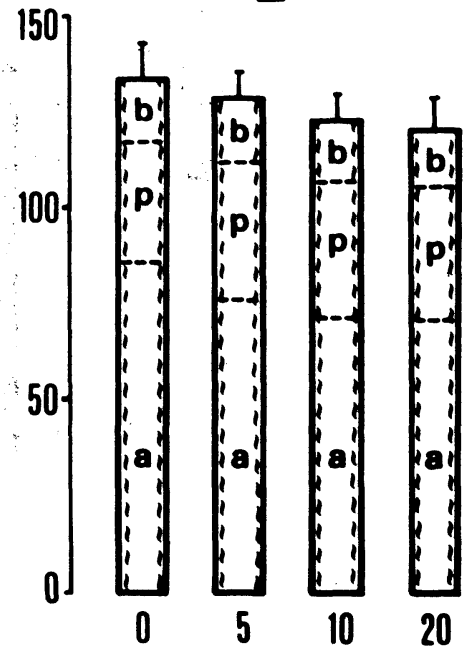

Tylosin $(m g / l)$

Fig. 2. Effect of tylosin on in vitro rumen fermentation with inocula from adapted wethers. Substrates were glucose (I), starch (II), cellulose (III) and pectin (IV).

$\mathrm{a}$ - acetate, $\mathrm{p}$ - propionate, $\mathrm{b}$ - butyrate 


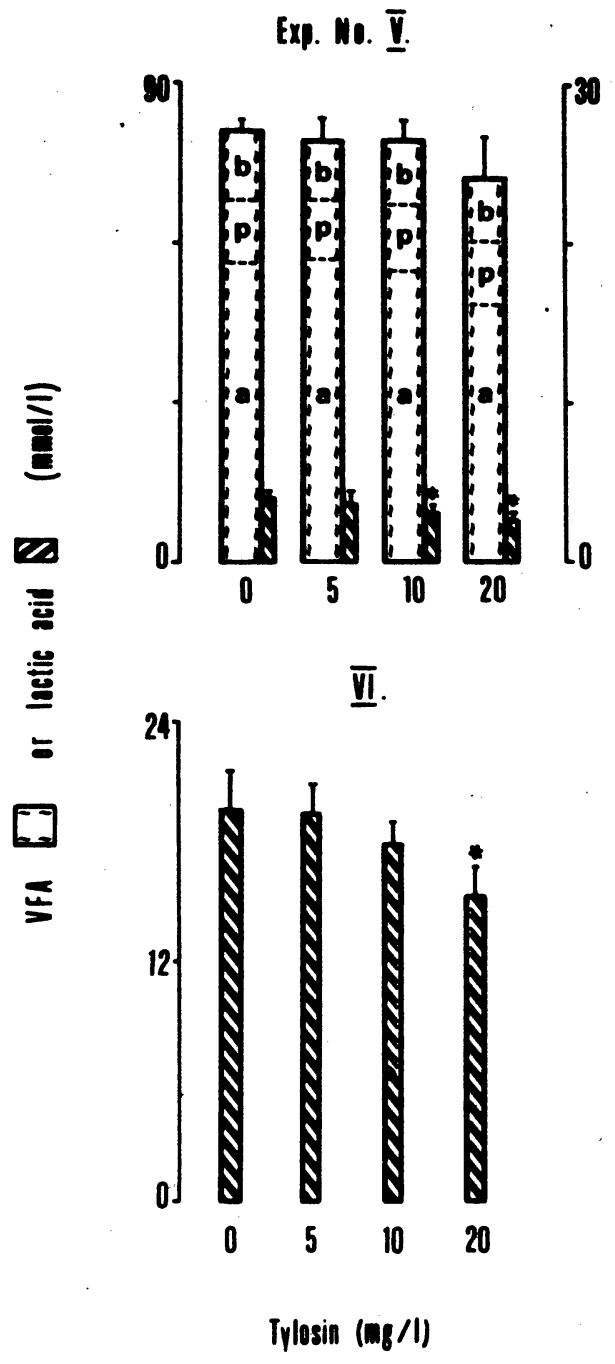

Fig. 3. Effect of tylosin on in vitro rumen fermentation with inocula from adapted wethers. Substrates were glucose and starch at low $\mathrm{pH}(\mathrm{V})$ and lactate (V). $\mathrm{a}$ - acetate, $\mathrm{p}$ - propionate, $\mathrm{b}$ - buryrate $*-\mathrm{P}<0.025$ 
Exp. Mo. 前.

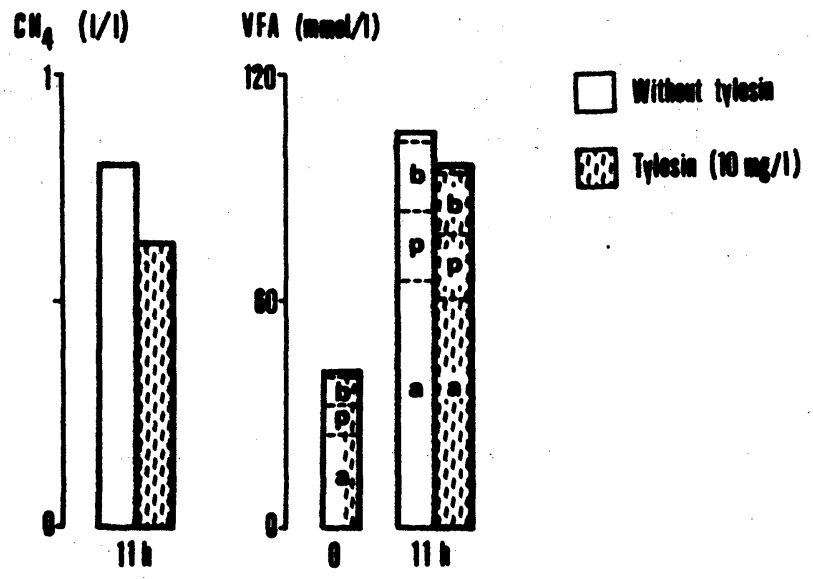

Fig. 4. Effect of tylosin on in vitro production of methane and VFA from glucose with inocula from adapted wethers.

a - acetate, p - propionate, b - butyrate

Exp. No. IIII.

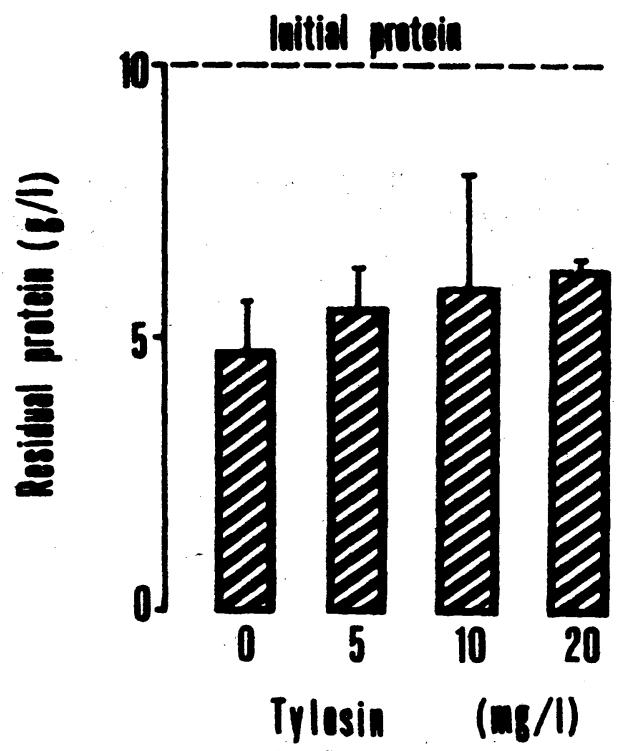

Fig. 5. Effect of tylosin on in vitro fermentation of casein with inocula from adapted wethers. 


\section{Úxinek tylosinu na bachorovou fermentaci in vitro}

Zjištovali jsme účinek tylosinu na tvorbu konečných produktú metabolismu sacharidủ, utilizaci kyseliny mléčné a odbourání proteinu v pokusech in vitro $s$ bachorovou tekutinou. Tylosin nespecificky inhiboval bachorovou fermentaci bylo-li inokulum vzato $\mathrm{z}$ neadaptovaných krav. Jeho vliv na fermentaci byl malý, bylo-li inokueum vzato ze skopců adaptovaných na prrijem tylosinu. Produkce kyseliny mléčné byla tylosinem za všech okolností výrażně potlačena. Pł̌estože tylosin, podobně jako ionofory, inhibuje rủst grampositivních bakterii, nejsou jím zpủsobené posuny ve složeni metabolitủ zcela stejné.

\section{Воздейстиие тилозина на ферментацию рубда ин витро}

Устанавливали воздействие тилозина на образование конечных продуктов метаболизма сахаридов, утилизацию молочной кислоты и расщепление протеина в ходе экспериментов в пробирках с жидкостью рубца. Тирозин неспецифически ингибировал ферментацию рубца при получении инокуляционного вещества у неадаптированных коров. Его влияние на ферментацию было небольшим при получении данного вещества у холощеных баранов, приспособленных к приему тилозина. Продукция молочной кислоты при всех обстоятельствах была тилозином существенно приторможена. Несмотря на то, что тилозин подобно ионофорам ингибирует рост граммположительных бактерий, вызванные им сдвиги в составе метаболитов не являются совершенно одинаковыми.

\section{References}

BEEDE, D. K. - FARLIN, S. D.: Effects of antibiotics on apparent lactate and volatile fatty acid production: In vitro rumen fermentation studies. J. Anim. Sci, 45, 1977, 385-392.

BROWN, H. - ELLISTON, N. G. - MCASKILL, J. W. - MUENSTER, O. A - TONKINSON, L. V.: Tylosin phosphate (TP) and tylosin urea adduct (TUA) for the prevention of liver abscesses, improved weight gains and feed efficiency in feedlot cattle. J. Anim. Sci., 37, 1973, 1085-1091.

CONWAY, E. J.: Microdiffusipn Analysis and Volumetric Error, 4th ed., pp. 248-278. London: Crosby Lockwood an Són, 1957.

EL AKKAD, I. - HOBSON, P. N.: Effect of antibiotics on some rumen and intestinal bacteria. Nature, 209, 1966, 1046-1047.

GILL, D. R. - OWENS, F. N.: Narasin, actaplanin and tylosin for feedlot steers. Oklahoma Agric. Exp. Station, Anim, Sci. Res. Report 1984, 198-203.

HEINEMANN, W. W. - HANKS, E. M. - YOUNG, D. C.: Monensin and tylosin in a high energy diet for finishing steers. J. Anim. Sci., 47, 1978, 34-40.

LOWRY, O. H. - ROSEBROUGH, N. J. - FARR, A. L. - RANDALL, R. J.: Protein measurement with the Folin phenol reagent. J. Biol. Chem. 193, 1951, 265-275.

MAROUNEK, M. - BARTOS, S.: Participation of microorganisms adherent on plant fibres in the breakdown of carbohydrates and in the metabolism of lactic acid in the rumen. Z. Tierphysiol., Tierernährg. u. Futtermittelkde. 49, 1983, 66-79.

MAROUNEK, M. - SIMƯNEK, J. - BARTOS, S. - KOLOUCH, F.: The effect of monensin on the production of lactic acid in rumen liquor in vitro. (In Czech.) Biol. chem. Vet. (Praha) XXIV (XXX), 1988, 69-74. 
MAROUNEK, M. - CHON, S. B. - PODSEDNIČEK, M.: Effect of antimicrobial feed additives on growth of pure cultures of ruminal bacteria. (In Czech). Biol. chem. Vet. (Praha), XXV (XXXI), 1989.

NAGARAJA, T. G. - TAYLOR, M. B.: Susceptibility and resistance of ruminal bacteria to antimicrobial feed additives. Appl. Environ. Microbiol., 53, 1987, 1620-1625.

O'CONNOR, J. J. - MYERS, G. S., Jr. - MAPLESDEN, D. C. - VANDER NOOT, G. W.: Chemical additives in rumen fermentations: In vitro effects of various drugs on rumen volatile fatty acids and protozoa. J. Anim. Sci., 30, 1970, 812-818.

POTTER, E. L. - WRAY, M. I. - MULLER, R. D. - GRUETER, H. P. - McASKIIL, J. - YOUNG, D. C.: Effects of monensin and tylosin on average daily gain, feed efficiency and liver abscess incidence in feedlot cattle. J. Anim. Sci.. 61, 1985, 1058.

PURSER D. B. - KLOPFENSTEIN, T. J. - CLINE J. H.: Influence of tylosin and aureomycin upon rumen metabolism and the microbial population. J. Anim. Sci., 24, 1965, 1039-1044.

RUSSELL, J. B. - STROBEL, H. J.: Effects of additives on in vitro ruminal fermentation: A comparison of monensin and bacitracin, another gram-positive antibiotic. J. Anim. Sci., 66, 1988, 552-558.

STRASIA, C. A. - JORDAN, L. J.: Comparison of ionophores for feedlot heifers: Lasalocid a. m. plus oxytetracycline p. m. - vs - continuous monensin-tylosin. Oklahoma Agric. Exp. Station, Anim. Sci. Res. Report 1985, 276-280.

WANG, C. - L. - BALDWIN, B. B. - FULGHUM, R. S. - WILLIAMS, P. P.: Quantitative antibiotic sensitivities of ruminal bacteria. Appl. Microbiol., 18, 1969, 677-679. 